\title{
PERTUMBUHAN DAN PRODUKSI BAWANG MERAH (Allium ascalonicum L.) DENGAN PEMBERIAN TRICHOKOMPOS TANDAN KOSONG KELAPA SAWIT TERFORMULASI DAN PUPUK KALIUM
}

\author{
Nofripa Herlina ${ }^{1}$, Nelvia ${ }^{2}$, Fifi Puspita ${ }^{2}$ \\ 1. Mahasiswa Pascasarjana Program Magister Ilmu Pertanian UR \\ 2. Dosen Fakultas Pertanian UR \\ Program Studi Magister Ilmu Pertanian \\ Jurusan Agroteknologi Fakultas Pertanian Universitas Riau \\ Kampus Binawidya Pekanbaru, 28293, Indonesia \\ nofripaherlina@rocketmail.com
}

\begin{abstract}
ABSTRAK
Penelitian bertujuan untuk mempelajari pengaruh interaksi pemberian Trichokompos tandan kosong kelapa sawit (TKKS) terformulasi dan pupuk kalium, pengaruh utama keduanya terhadap pertumbuhan dan produksi bawang merah (Allium ascalonicum L.) di lahan gambut. Penelitian dilakukan secara eksperimen dalam bentuk faktorial $4 \mathrm{x}$ 3 disusun menggunakan Rancangan Acak Lengkap (RAL). Trichokompos TKKS terformulasi sebagai faktor I terdiri dari 4 taraf $(15,20,25$ dan 30 ton/ha) dan pupuk kalium sebagai faktor II terdiri dari 3 taraf (50, 100 dan 150 $\mathrm{kg} \mathrm{K}_{2} \mathrm{O} / \mathrm{ha}$ ). Parameter yang diamati antara lain tinggi tanaman, jumlah umbi berdasarkan kriteria diameter dan bobot segar umbi per rumpun sampel. Hasil penelitian menunjukkan bahwa pemberian 25 ton/ha Trichokompos TKKS terformulasi dan $100 \mathrm{~kg} \mathrm{~K}$ O/ha mengurangi umbi diameter kecil sebesar 3 kali (228,6\%), sebaliknya meningkatkan umbi diameter besar sebesar 24 kali $(2324,2 \%)$ dan bobot segar umbi per rumpun sampel sebesar 1,7 kali $(71,3 \%)$ dibandingkan pemberian 15 ton/ha pada dosis pupuk kalium yang sama $\left(100 \mathrm{~kg} \mathrm{~K}_{2} \mathrm{O} / \mathrm{ha}\right)$. Peningkatan dosis Trichokompos TKKS terformulasi dari 15 ke 25 ton/ha mengurangi umbi diameter kecil, sebaliknya meningkatkan umbi diameter besar dan bobot segar umbi per rumpun sampel. Peningkatan dosis ke 30 ton/ha masih berpengaruh terhadap peningkatan parameter tersebut kecuali jumlah umbi diameter kecil dan jumlah umbi diameter besar. Peningkatan dosis pupuk kalium dari $50 \mathrm{ke} 100$ hingga $150 \mathrm{~kg} \mathrm{~K} \mathrm{~K}_{2} \mathrm{O} / \mathrm{ha}$ tidak mempengaruhi seluruh parameter yang diamati.
\end{abstract}

Kata kunci: Bawang merah, Tricho-kompos TKKS terformulasi, pupuk kalium dan gambut

\section{PENDAHULUAN}

Sebagian besar penduduk Indonesia menggunakan bawang merah (Allium ascalonicum L.) sebagai campuran bumbu masakan sehari-hari. Meskipun disadari bahwa bawang merah bukan merupakan kebutuhan pokok, akan tetapi kebutuhannya hampir tidak dapat dihindari oleh konsumen rumah tangga. Seiring bertambahnya jumlah penduduk khususnya di Provinsi Riau, permintaan konsumen terhadap bawang merah terus meningkat, sedangkan produksi bawang merah di Riau sangat rendah yaitu 12 ton/tahun (BPS, 2013). Selama ini untuk memenuhi kebutuhan masyarakat di Riau terhadap bawang merah selalu diimpor dari luar Riau.

Riau sangat berpotensi untuk pengembangan budidaya bawang merah jika dilihat dari syarat tumbuh, diantaranya yaitu bawang merah menghendaki tanah yang subur, gembur dan kaya bahan organik, suhu udara yang sesuai antara $25^{\circ} \mathrm{C}-32^{\circ} \mathrm{C}$ (Balitsa, 2013) serta cocok ditanam di dataran rendah (Purbiati, 2012). Berdasarkan syarat tumbuh tersebut, maka perlu dilakukan pengembangan budidaya bawang merah di Riau. Namun, saat ini ketersediaan lahan subur di Riau semakin terbatas, sehingga perlu alternatif dengan memanfaatkan lahan marginal. Salah satu lahan marginal yang ada di Riau adalah lahan gambut.

Riau memiliki lahan gambut terluas di Sumatera yaitu 3.867.414 ha (BBSDLP, 2011) atau $60,1 \%$ dari luas lahan gambut Sumatera, yaitu 6.436.649 ha (Badan Penelitian dan Pengembangan Pertanian, 2011). Dinas Pertanian Tanaman Pangan Provinsi Riau dalam Murniati et al. (2010) menyatakan bahwa lahan gambut yang potensial untuk pengembangan 
tanaman pangan seluas 878.751 ha dan baru termanfaatkan 36\% (31.650 ha).

Pengembangan budidaya bawang merah di lahan gambut memiliki kendala dari segi kimia tanah. Tanah gambut memiliki $\mathrm{pH}$ rendah, kejenuhan basa (KB) rendah, kapasitas tukar kation (KTK) tinggi, kandungan unsur hara makro $(\mathrm{K}, \mathrm{Ca}, \mathrm{Mg}, \mathrm{P})$ dan unsur hara mikro $(\mathrm{Cu}$, Zn, Mn dan B) yang rendah (Ratmini, 2012). Sementara itu, untuk melangsungkan pertumbuhan dan produksi bawang merah memerlukan unsur hara makro dan mikro yang cukup dan seimbang. Untuk meningkatkan ketersediaan hara tersebut dapat dilakukan melalui pemberian pupuk organik (kompos) maupun anorganik. Salah satu bahan organik yang diberikan yaitu tandan kosong kelapa sawit (TKKS).

Nelvia, et al. (2012) melaporkan bahwa kompos TKKS mengandung hara lengkap dan jumlahnya melimpah, sehingga dapat dimanfaatkan sebagai sumber bahan organik. Darnoko, et al. (2006) dalam Nelvia, et al. (2012) melaporkan bahwa kompos TKKS dengan C/N 15,0 mengandung 29,76\% C, 1,98\% $\mathrm{N}, 0,022 \% \mathrm{P}, 3,45 \% \mathrm{~K}, 0,72 \% \mathrm{Ca}, 0,54 \% \mathrm{Mg}$ dan 54,39\% air. Hasil penelitian Yulia, et al. (2011) tentang aplikasi pupuk organik pada tanaman caisim menunjukkan bahwa kompos tandan kosong kelapa sawit (TKKS) lebih baik dari jenis pupuk organik lainnya.

Tandan kosong kelapa sawit (TKKS) sangat sulit terdekomposisi secara alami. Untuk mempercepat proses dekomposisi ditambahkan Trichoderma sp. sebagai dekomposer sehingga disebut Trichokompos TKKS. Untuk meningkatkan kualitas Trichokompos TKKS yang dihasilkan, maka dilakukan pengkayaan dengan penambahan zeolit dan tepung tapioka yang disebut Trichokompos TKKS terformulasi. Ichwan (2007) melaporkan bahwa pemberian Trichokompos dengan berbagai dosis nyata meningkatkan pertumbuhan dan hasil tanaman cabe merah.

Penambahan pupuk anorganik khususnya kalium untuk pertumbuhan dan produksi bawang merah dilahan gambut sangat dibutuhkan. Hal ini disebabkan ketersediaan unsur hara kalium di tanah gambut sangat rendah (Sasli, 2011). Idwar, et al. (2014) melaporkan bahwa kandungan unsur $\mathrm{K}$ di lahan gambut Desa Kualu Nenas Kecamatan Tambang Kabupaten Kampar yaitu $\mathrm{K}_{2} \mathrm{O} 16 \mathrm{mg} / 100$ g, yang termasuk ke dalam kriteria rendah untuk sifat kimia tanah.

Kebutuhan hara $\mathrm{K}$ untuk bawang merah dataran rendah yaitu $50-100 \mathrm{~kg} \mathrm{~K}_{2} \mathrm{O} / \mathrm{ha}$ atau $100-200 \mathrm{~kg} \mathrm{KCl} / \mathrm{ha}$ (Sumarni dan Hidayat, 2005), Sitepu, et al. (2011) melaporkan bahwa pemberian pupuk $\mathrm{KCl} 200 \mathrm{~kg} /$ ha dihasilkan diameter umbi terbesar, bobot basah umbi per sampel dan bobot kering umbi per sampel terberat yaitu masing-masing sebesar $3,72 \mathrm{~cm}$, $18,69 \mathrm{~g}$ dan 5,61 g secara berurutan.

Berdasarkan uraian di atas, maka pemberian Trichokompos TKKS terformulasi dan pupuk Kalium di lahan gambut sangat diperlukan untuk menunjang pertumbuhan dan produksi bawang merah. Namun, dosis yang tepat belum diketahui. Oleh sebab itu, dilakukan penelitian dengan judul "Pertumbuhan dan produksi bawang merah (Allium ascalonicum L.) dengan pemberian Trichokompos tandan kosong kelapa sawit terformulasi dan pupuk kalium di lahan gambut.

Penelitian bertujuan untuk mempelajari pengaruh interaksi pemberian Trichokompos TKKS terformulasi dan pupuk kalium, pengaruh utama keduanya terhadap pertumbuhan dan produksi bawang merah (Allium ascalonicum $\mathrm{L}$.) di lahan gambut.

\section{METODOLOGI PENELITIAN}

Penelitian dilaksanakan di Kebun Percobaan Fakultas Pertanian Universitas Riau yang terletak di Rimbo Panjang Kab. Kampar Provinsi Riau. Jenis tanah gambut dengan tingkat kematangan saprik dan topografi datar, dilaksanakan dari Oktober sampai Desember 2014.

Penelitian dilaksanakan di lahan gambut, kebun percobaan Fakultas Pertanian Universitas Riau yang terletak di Rimbo Panjang Kab. Kampar Provinsi Riau. Tingkat kematangan saprik dan topografi datar, dilaksanakan dari Oktober sampai Desember 2014. 
Bahan yang digunakan yaitu bibit bawang merah varietas Bauji, Trichokompos TKKS terformulasi (Trichoderma sp. + tandan kosong kelapa sawit + zeolit + tepung tapioka), Urea, TSP, $\mathrm{KCl}$, mulsa, insektisida Curaccron dan fungisida Dithane M-45. Alat yang digunakan antara lain timbangan elektrik, oven, jangka sorong, sentrifus, spektrofotometer, flamefotometer, Atomic absorption spectrophotometer (AAS), alat tulis dan alat-alat lainnya yang mendukung penelitian.

Penelitian dilakukan secara eksperimen dalam bentuk faktorial 4 x 3 yang disusun menggunakan Rancangan Acak Lengkap (RAL). Sebagai faktor I adalah Trichokompos TKKS terformulasi terdiri dari 4 taraf, dan pupuk kalium sebagai faktor II terdiri dari 3 taraf. Adapun taraf masing-masing faktor adalah sebagai berikut:

Faktor I:

T1 : 15 ton Trichokompos TKKS terformulasi/ ha

T2 : 20 ton Trichokompos TKKS terformulasi/ ha

T3 : 25 ton Trichokompos TKKS terformulasi/ ha

T4 : 30 ton Trichokompos TKKS terformulasi/ ha

Faktor II:

$\begin{array}{lll}\mathrm{K} 1 & : & 50 \mathrm{~kg} \mathrm{~K}_{2} \mathrm{O} / \text { ha } \\ \mathrm{K} 2 & : & 100 \mathrm{~kg} \mathrm{~K}_{2} \mathrm{O} / \mathrm{ha} \\ \mathrm{K} 3 & : & 150 \mathrm{~kg} \mathrm{~K}_{2} \mathrm{O} / \text { ha }\end{array}$

Dua faktor di atas menghasilkan kombinasi perlakuan sebanyak $4 \times 3=12$ kombinasi dengan 3 ulangan menjadi 36 satuan percobaan. Model linier yang digunakan adalah:

$\mathrm{Y}_{\mathrm{ijk}}=\mu+\alpha_{\mathrm{i}}+\beta_{\mathrm{j}}+(\alpha \beta)_{\mathrm{ij}}+\varepsilon_{\mathrm{ijk}}$

dimana:

$\mathrm{Y}_{\mathrm{ijk}} \quad$ : nilai pengamatan pada satuan percobaan ke-k yang memperoleh kombinasi perlakuan ij (taraf ke-i dari faktor dosis Trichokompos terformulasi dan taraf ke-j dari faktor dosis pupuk kalium).
$\mu$
: nilai tengah populasi
$\alpha_{i}$ : pengaruh aditif Trichokompos TKKS
terformulasi pada taraf ke-i
$\beta_{\mathrm{j}}$ : pengaruh aditif pupuk kalium pada taraf ke-j $(\alpha \beta)_{\mathrm{ij} j}: \quad$ pengaruh interaksi Trichokompos TKKS terformulasi pada taraf kei dan pupuk kalium pada taraf ke-j.

$\varepsilon_{\mathrm{ijk}} \quad:$ Pengaruh galat Trichokompos TKKS terformulasi pada taraf ke-i, perlakuan pupuk kalium taraf ke-j dan pada ulangan taraf ke-k

$$
\begin{array}{ll}
\mathrm{i} & : 1,2,3,4 \\
\mathrm{j} & : 1,2,3 \\
\mathrm{k} & : 1,2,3
\end{array}
$$

Data hasil pengamatan dianalisis secara statistik menggunakan analisis ragam. Jika hasil sidik ragam berpengaruh nyata akan di uji lanjut dengan menggunakan Duncan New Multiple Range Test (DNMRT) pada taraf 5\%.

\section{Pelaksanaan Penelitian}

Lahan yang digunakan dibersihkan dari gulma. Kemudian lahan diolah dan digemburkan menggunakan cangkul hingga kedalaman $20 \mathrm{~cm}$. Kemudian plot tanaman setiap unit percobaan dibuat dengan ukuran $1 \mathrm{~m}$ x $1,5 \mathrm{~m}$ x $30 \mathrm{~cm}$, jarak antar plot $30 \mathrm{~cm}$. Kemudian plot diberi label. Perlakuan yang digunakan yaitu Trichokompos TKKS terformulasi dan $\mathrm{KCl}$ dengan dosis sesuai perlakuan. Pemberian Trichokompos TKKS terformulasi dilakukan 1 kali yaitu 1 minggu sebelum tanam dengan cara disebar lalu diaduk rata dengan tanah, sedangkan pupuk $\mathrm{KCl}$ diberikan tiga kali, yaitu $1 / 3$ pada saat tanam, 1/3 pada umur 15 hari setelah tanam (HST) dan $1 / 3$ pada umur $30 \mathrm{HST}$. Pemberian pupuk $\mathrm{KCl}$ dilakukan dengan cara menaburkannya diantara baris tanaman. Pupuk dasar adalah urea dan TSP, masing-masing dengan dosis $200 \mathrm{~kg} \mathrm{~N} / \mathrm{ha}$ dan $90 \mathrm{~kg} \mathrm{P}_{2} \mathrm{O}_{5} / \mathrm{ha}$. Pemberian pupuk dasar dilakukan 3 hari sebelum tanam, masing-masing $1 / 2$ dosis anjuran, diberikan dengan cara disebar lalu diaduk rata dengan tanah.

Bibit bawang merah ditanam dengan cara tugal, yaitu dimasukkan ke dalam lubang tanaman dengan gerakan memutar, sehingga ujung umbi tampak rata dengan permukaan tanah. Jarak tanam $20 \mathrm{~cm}$ x $20 \mathrm{~cm}$.

Parameter yang diamati antara lain tinggi tanaman, jumlah umbi berdasarkan kriteria diameter dan bobot segar umbi per sampel. 
3. HASIL DAN PEMBAHASAN

Sifat Kimia Tanah Gambut

Sifat Kimia Tanah Gambut

Hasil analisis sifat kimia tanah gambut yang digunakan dalam penelitian disajikan pada Tabel 1.

Tabel 1. Sifat kimia tanah gambut yang digunakan dalam penelitian

\begin{tabular}{|c|c|c|}
\hline Sifat Kimia & Nilai & Kriteria \\
\hline $\mathrm{pH} \mathrm{H}_{2} \mathrm{O}$ & 5,1 & Masam \\
\hline $\mathrm{KCl}$ & 4,7 & Masam \\
\hline C-Organik (\%) & 20,8 & Sangat Tinggi \\
\hline N Total (\%) & 0,78 & Sangat Tinggi \\
\hline $\mathrm{C} / \mathrm{N}$ & 26,5 & Sangat Tinggi \\
\hline $\begin{array}{l}\mathrm{P}_{2} \mathrm{O}_{5}(\mathrm{HCl} 25 \% \\
(\mathrm{mg} / 100 \mathrm{~g})\end{array}$ & 608,7 & Sangat Tinggi \\
\hline $\begin{array}{l}\mathrm{K}_{2} \mathrm{O}(\mathrm{HCl} 25 \% \\
(\mathrm{mg} / 100 \mathrm{~g})\end{array}$ & 8,47 & Sangat Rendah \\
\hline $\begin{array}{l}\text { P-Bray } \\
\text { (mg/kg) }\end{array}$ & 1046 & Sangat Tinggi \\
\hline $\begin{array}{l}\text { KTK } \\
\left(\mathrm{cmol}^{(+)} / \mathrm{kg}\right) \\
\text { Kejenuhan basa }\end{array}$ & 96,1 & Sangat Tinggi \\
\hline$(\mathrm{KB})(\%)$ & 43,5 & Sedang \\
\hline $\begin{array}{l}\text { Kation dapat } \\
\text { ditukar } \\
\left(\mathrm{cmol}^{(+)} / \mathrm{kg}\right)\end{array}$ & 0,75 & Tinggi \\
\hline
\end{tabular}

\begin{tabular}{lcc}
\hline Sifat Kimia & Nilai & Kriteria \\
\hline K-dd & & \\
\hline Ca-dd & 38,4 & Sangat Tinggi \\
Mg-dd & 2,53 & Tinggi \\
Na-dd & 0,16 & Rendah \\
\hline *) Sumber: Pusat Penelitian & Tanah, (1983) dalam \\
Hardjowigeno, (1995) & \\
\multicolumn{2}{c}{ Tabel 1 menunjukkan } & bahwa sifat kimia
\end{tabular}
tanah gambut yang digunakan dalam penelitian merupakan jenis tanah marjinal dengan tingkat kesuburan sedang. Hal ini terlihat dari $\mathrm{C} / \mathrm{N}, \mathrm{N}$ total, $\mathrm{P}$ potensial, $\mathrm{P}$ tersedia dan KTK yang tergolong sangat tinggi, (K-dd, Mg-dd, Ca-dd) tergolong tinggi - sangat tinggi, sedangkan KB tergolong sedang.

Nilai pH, C-Organik, KTK dan K Potensial Tanah Gambut yang Diaplikasi Trichokompos TKKS Terformulasi dan Pupuk Kalium Setelah Panen

Hasil analisis tanah terhadap nilai $\mathrm{pH}, \mathrm{C}$ Organik, KTK dan K Potensial tanah gambut yang diaplikasi Trichokompos TKKS terformulasi dan pupuk kalium setelah panen disajikan pada Tabel 2.

Tabel 2. Nilai pH, C-Organik, KTK dan K Potensial tanah gambut yang diaplikasi Trichokompos TKKS terformulasi dan pupuk Kalium setelah panen

\begin{tabular}{cccccc}
\hline Perlakuan & \multicolumn{5}{c}{ Sifat Kimia dan Kriteria } \\
\hline $\begin{array}{c}\text { Trichokompos } \\
\text { TKKS } \\
\text { terformulasi } \\
\text { (ton/ha) }\end{array}$ & $\mathrm{H}_{2} \mathrm{O}$ & $\mathrm{KCl}$ & $\%$ & $\mathrm{KTK}$ & $\begin{array}{c}\text { K potensial } \\
(\mathrm{HCl} 25 \%) \\
\mathrm{cmol}^{(+)} / \mathrm{kg}\end{array}$ \\
\hline 15 & $5,1(\mathrm{M})$ & $4,8(\mathrm{M})$ & $18,6(\mathrm{ST})$ & $91,3(\mathrm{ST})$ & $4,92(\mathrm{SR})$ \\
20 & $5,3(\mathrm{M})$ & $4,7(\mathrm{M})$ & $26(\mathrm{ST})$ & $94,9(\mathrm{ST})$ & $9,13(\mathrm{SR})$ \\
25 & $5,3(\mathrm{M})$ & $4,9(\mathrm{M})$ & $26,9(\mathrm{ST})$ & $94,3(\mathrm{ST})$ & $268,7(\mathrm{ST})$ \\
30 & $5,6(\mathrm{AM})$ & $5,2(\mathrm{M})$ & $26,3(\mathrm{ST})$ & $86,2(\mathrm{ST})$ & $283,2(\mathrm{ST})$ \\
\hline
\end{tabular}

Ket: M: Masam; AM: Agak Masam; ST: Sangat Tinggi; SR: Sangat Rendah

Tabel 2 menunjukkan bahwa peningkatan dosis Trichokompos TKKS terformulasi dari 15 ke 20 hingga 30 ton/ha dapat meningkatkan pH tanah gambut dari masam menjadi agak masam. Peningkatan nilai $\mathrm{pH}$ disebabkan terjadinya interaksi antara senyawa organik yang berupa asam humat dan fulvat dari Trichokompos TKKS terformulasi dengan senyawa organik dari tanah gambut membentuk molekul yang lebih besar dan stabil, sehingga tidak menyumbangkan lagi ion $\mathrm{H}^{+}$.
Tabel 2 juga menunjukkan bahwa terjadi peningkatan kandungan C-organik pada penambahan Trichokompos TKKS terformulasi. Hal ini disebabkan penambahan Trichokompos TKKS terformulasi dapat meningkatkan kandungan C-organik di dalam tanah. Yasin, et al. (2010) melaporkan bahwa lebih dari $90 \%$ jaringan bahan organik mengandung unsur $\mathrm{C}$, yang apabila ditambahkan ke dalam tanah maka akan meningkatkan kandungan unsur $\mathrm{C}$ organik tanah. 
KTK tanah setelah panen tetap pada kriteria sangat tinggi. Hal ini terjadi karena bahan organik yang terdekomposisi dapat menghasilkan asam organik yang meningkatkan gugus karboksil $-\mathrm{COOH}$ dan fenolik $-\mathrm{OH}$ sehingga muatan negatif ikut meningkat pula. Menurut Herviyanti, et al. (2012) bahwa peningkatan muatan negatif pada koloid tanah dapat menyebabkan peningkatan KTK pada tanah. Mustoyo (2013) melaporkan bahwa penambahan bahan organik yang semakin tinggi dapat memberikan nilai KTK yang semakin tinggi pula.

\section{Tinggi Tanaman}

Hasil sidik ragam menunjukkan bahwa pemberian Trichokompos TKKS terformulasi, pupuk kalium dan interaksi keduanya berpengaruh tidak nyata terhadap tinggi tanaman bawang merah. Hasil uji lanjut dengan DNMRT taraf 5\% disajikan pada Tabel 3.

Tabel 3. Tinggi tanaman bawang merah $(\mathrm{cm})$ umur 45 HST pada lahan gambut dengan pemberian Trichokompos TKKS terformulasi dan pupuk kalium

\begin{tabular}{cccc}
\hline $\begin{array}{c}\text { Trichokompos TKKS } \\
\text { terformulasi } \\
\text { (ton/ha) }\end{array}$ & 50 & 100 & Pupuk Kalium $\left(\mathrm{kg} \mathrm{K}_{2} \mathrm{O} / \mathrm{ha}\right)$ \\
\cline { 2 - 4 } & 25,60 & 25,24 & 27,63 \\
20 & 26,77 & 24,75 & 26,23 \\
25 & 27,30 & 27,22 & 26,83 \\
30 & 28,14 & 27,87 & 27,45 \\
\hline
\end{tabular}

Tabel 3 menunjukkan bahwa pemberian Trichokompos TKKS terformulasi dan pupuk kalium tidak terjadi interaksi secara nyata terhadap tinggi tanaman bawang merah, namun pemberian Trichokompos TKKS terformulasi 30 ton/ha dan pupuk kalium $50 \quad \mathrm{~kg} \quad \mathrm{~K}_{2} \mathrm{O} / \mathrm{ha}$ cenderung menghasilkan tinggi tanaman tertinggi atau meningkat sebesar 13,8 \% dibandingkan dengan pemberian Trichokompos TKKS terformulasi 20 ton/ha dan pupuk kalium $100 \mathrm{~kg} \mathrm{~K} \mathrm{~K}_{2} \mathrm{O} / \mathrm{ha}$. Tidak terjadinya interaksi diduga terjadi kehilangan unsur hara karena tercuci oleh curah hujan yang relatif tinggi di awal penelitian, serta kurangnya intensitas matahari juga mengakibatkan terganggunya proses fotosintesis yang akan berpengaruh langsung terhadap pertumbuhan tanaman bawang merah.

Hidayat, et al. (2011) melaporkan bahwa bawang merah varietas Bauji yang ditanam di Brebes pada musim kemarau dihasilkan tinggi tanaman lebih tinggi dibandingkan di Tegal dan di Nganjuk yaitu dengan tinggi tanaman berturut-turut $39,93 \mathrm{~cm}, 33,07 \mathrm{~cm}$ dan $33,40 \mathrm{~cm}$. Hasil penelitian Purbiati, et al. (2010) tentang uji varietas bawang merah di lahan gambut dataran rendah Kabupaten Kuburaya Kalimantan Barat menunjukkan bahwa bawang merah varietas Bauji yang diberi pupuk dasar kandang ayam ditambah pupuk organik pabrik 10 ton/ha berumur 30 HST diperoleh tinggi tanaman 18,72 $\mathrm{cm}$.

Hasil penelitian Nadeak, et al. (2014) menunjukkan bahwa pemberian Tricho-kompos serasah jagung 25 ton/ha memberikan tinggi tanaman sawi tertinggi. Ichwan (2007) menyatakan bahwa pemberian Tricho-kompos diduga lebih cenderung memperbaiki sifat fisik dan biologi tanah mengingat bahan organik yang dikandung dalam Trichokompos.

\section{Jumlah Umbi Berdasarkan Kriteria Diameter Kecil (< 1,5 cm), dan Besar (> $1,8 \mathrm{~cm}$ )}

Hasil sidik ragam menunjukkan bahwa pemberian Trichokompos TKKS terformulasi berpengaruh nyata terhadap jumlah umbi diameter kecil dan besar, sedangkan pemberian pupuk kalium dan interaksi keduanya berpengaruh tidak nyata terhadap jumlah umbi diameter kecil, sedang dan besar. Hasil uji lanjut dengan DNMRT taraf $5 \%$ disajikan pada Tabel 4. 
Tabel 4. Jumlah umbi bawang merah (umbi) berdasarkan kriteria diameter kecil dan besar di lahan gambut dengan pemberian Trichokompos TKKS terformulasi dan pupuk kalium

\begin{tabular}{|c|c|c|c|c|}
\hline \multirow{2}{*}{$\begin{array}{l}\text { Tricho-kompos } \\
\text { (ton/ha) }\end{array}$} & 50 & 10 & 15 & \multirow{2}{*}{ Rata-rata } \\
\hline & \multicolumn{3}{|c|}{ Umbi diameter kecil } & \\
\hline 15 & $16,00 a b$ & $23,00 \mathrm{a}$ & $16,33 a b$ & $18,44 \mathrm{a}$ \\
\hline 20 & $23,00 \mathrm{a}$ & $15,00 \mathrm{abc}$ & $9,66 \mathrm{bcd}$ & $15,88 \mathrm{a}$ \\
\hline 25 & $7,33 \mathrm{bcd}$ & $7,00 \mathrm{bcd}$ & $4,33 \mathrm{bcd}$ & $6,22 \mathrm{~b}$ \\
\hline 30 & $2,33 \mathrm{~cd}$ & 6,66 bcd & $1,00 \mathrm{~d}$ & $3,33 \mathrm{~b}$ \\
\hline \multicolumn{5}{|c|}{ Umbi diameter besar } \\
\hline 15 & $2,00 \mathrm{c}$ & $0,66 \mathrm{c}$ & $3,66 \mathrm{c}$ & $2,11 \mathrm{~b}$ \\
\hline 20 & $4,00 \mathrm{c}$ & $5,00 \mathrm{c}$ & $9,00 \mathrm{bc}$ & $6,00 \mathrm{~b}$ \\
\hline 25 & $9,33 \mathrm{bc}$ & $16,00 \mathrm{ab}$ & $13,66 \mathrm{ab}$ & $13,00 \mathrm{a}$ \\
\hline 30 & $16,00 \mathrm{ab}$ & $15,33 a b$ & $20,66 \mathrm{a}$ & $17,33 \mathrm{a}$ \\
\hline
\end{tabular}

Pupuk Kalium ( $\left.\mathrm{kg} \mathrm{K}_{2} \mathrm{O} / \mathrm{ha}\right)$

Angka-angka yang diikuti oleh huruf kecil pada kolom dan baris yang sama berbeda tidak nyata menurut uji Duncan pada taraf $5 \%$

Tabel 4 menunjukkan bahwa pemberian Trichokompos TKKS terformulasi 25 ton/ha dan pupuk kalium $100 \mathrm{~kg} \mathrm{~K}_{2} \mathrm{O} /$ ha mengurangi umbi diameter kecil 3 kali $(228,6 \%)$, sebaliknya meningkatkan umbi berdiameter besar hingga 24 kali (2324,2\%) dibandingkan pemberian 15 ton/ha pada dosis pupuk kalium yang sama (100 $\mathrm{kg} \mathrm{K}_{2} \mathrm{O} / \mathrm{ha}$ ). Peningkatan dosis Trichokompos TKKS terformulasi hingga 30 ton/ha tidak begitu besar pengaruhnya terhadap jumlah umbi diameter kecil maupun besar. Hal ini disebabkan interaksi antara Trichokompos TKKS terformulasi 25 ton/ha dan pupuk kalium $100 \mathrm{~kg}$ $\mathrm{K}_{2} \mathrm{O} / \mathrm{ha}$ memberikan nutrisi yang seimbang untuk mendukung proses metabolisme membentuk karbohidrat.

Tabel 4 juga menunjukkan bahwa peningkatan dosis Trichokompos TKKS terformulasi hingga 25 ton/ha mengurangi umbi diameter kecil sebesar 2,96 kali (196,5\%), sebaliknya meningkatkan umbi diameter besar hingga 6,16 kali $(516,1 \%)$ dibandingkan dengan pemberian 15 ton/ha. Hal ini disebabkan peningkatan dosis Trichokompos TKKS terformulasi tentu diikuti oleh peningkatan unsur hara di dalam tanah, terutama unsur hara $\mathrm{K}$. Mengingat unsur hara $\mathrm{K}$ sangat diperlukan dalam pembentukan dan pembesaran umbi. Unsur K yang dilepas dari Trichokompos TKKS terformulasi dalam jumlah yang tinggi menyebabkan terjadinya peningkatan kandungan klorofil, sehingga aktifitas fotosintesis meningkat. Tersedianya $\mathrm{K}$ yang cukup, dapat memacu translokasi hasil fotosintesis dari daun ke organ tanaman yang lain terutama umbi, sehingga dapat meningkatkan ukuran umbi.

Koheri, et al. (2015) menyatakan ketersediaan $\mathrm{K}$ yang cukup dan seimbang di dalam tanah sangat penting meningkatkan pertumbuhan tanaman, karena $\mathrm{K}$ berperan sebagai katalisator dalam pengubahan protein menjadi asam amino dan penyusun karbohidrat dan memacu translokasi hasil fotosintesis dari daun ke seluruh bagian tanaman terutama umbi yang dapat meningkatkan ukuran, jumlah dan hasil umbi. Hasil penelitian Hapsoh, et al. (2012) menunjukkan bahwa pemberian $\mathrm{KCl} 150$ $\mathrm{kg} / \mathrm{ha}$ dapat meningkatkan jumlah umbi ubi jalar ukuran besar.

Selain itu, tersedianya hara yang cukup disebabkan oleh hasil dekomposisi bahan organik Trichokompos TKKS terformulasi, dimana C/N Tricho-kompos TKKS terformulasi tergolong sedang yaitu 11,7 artinya Trichokompos TKKS terformulasi telah matang dan dapat menyediakan unsur hara bagi tanaman, terutama hara K. Refliaty (2013) menyatakan bahwa kompos yang memiliki C/N rendah - sedang akan mudah terdekomposisi.

Umbi yang berukuran kecil disebabkan unsur hara dalam pupuk Trichokompos TKKS terformulasi memang mendukung proses 
fotosintesis dan menghasilkan karbohidrat, tetapi karena dosis Trichokompos TKKS terformulasi yang diberikan rendah dibandingkan dosis Trichokompos TKKS terformulasi yang lebih tinggi, sehingga diduga suplai hara sedikit dan menghasilkan fotosintat yang juga sedikit, maka pembelahan sel pada jaringan vegetatif tidak diimbangi dengan pembesaran sel dan hasil fotosintat yang ditimbun pada umbi sedikit, akibatnya ukuran umbinya kecil. Hal ini sesuai dengan pernyataan Setiyowati, et al. (2010) bahwa ukuran umbi yang kecil merupakan indikasi bahwa kandungan senyawa organik dalam umbi seperti karbohidrat, protein, lemak sangat sedikit, sehingga komponen berat kering yang diperoleh juga relatif sedikit.

\section{Bobot Segar Umbi per Sampel}

Hasil sidik ragam menunjukkan bahwa pemberian Trichokompos TKKS terformulasi berpengaruh nyata terhadap bobot segar umbi per sampel, sedangkan pemberian pupuk kalium dan interaksi keduanya berpengaruh tidak nyata terhadap bobot segar umbi per sampel. Hasil uji lanjut dengan DNMRT taraf $5 \%$ disajikan pada Tabel 5.

Tabel 5. Bobot segar umbi per sampel (g/rumpun) dengan perlakuan Trichokompos TKKS terformulasi dan pupuk kalium di lahan gambut

\begin{tabular}{ccccc}
\hline $\begin{array}{c}\text { Trichokompos } \\
\text { TKKS terformulasi } \\
\text { (ton/ha) }\end{array}$ & \multicolumn{3}{c}{ Pupuk Kalium $\left(\mathrm{kg} \mathrm{K}_{2} \mathrm{O} / \mathrm{ha}\right)$} & Rata-rata \\
\cline { 2 - 4 } & 50 & 100 & 150 & \\
\hline 15 & $22,56 \mathrm{e}$ & $27,19 \mathrm{de}$ & $25,94 \mathrm{de}$ & $25,23 \mathrm{c}$ \\
20 & $26,59 \mathrm{de}$ & $27,01 \mathrm{de}$ & $33,25 \mathrm{cde}$ & $28,95 \mathrm{c}$ \\
25 & $37,62 \mathrm{bcd}$ & $46,58 \mathrm{abc}$ & $28,94 \mathrm{de}$ & $37,71 \mathrm{~b}$ \\
30 & $46,70 \mathrm{abc}$ & $59,94 \mathrm{a}$ & $50,71 \mathrm{ab}$ & $52,45 \mathrm{a}$ \\
\hline Rata-rata & $33,37 \mathrm{a}$ & $40,18 \mathrm{a}$ & $34,71 \mathrm{a}$ & \\
\hline
\end{tabular}

Angka-angka yang diikuti oleh huruf kecil pada kolom dan baris yang sama berpengaruh tidak nyata menurut uji Duncan pada taraf 5\%.

Tabel 5 menunjukkan bahwa pemberian Trichokompos TKKS terformulasi 25 ton/ha dan pupuk kalium $100 \mathrm{~kg} \mathrm{~K}$ O/ha meningkatkan bobot segar umbi per sampel sebesar 1,7 kali (71,3\%) dibandingkan dengan pemberian 15 ton/ha pada dosis pupuk kalium yang sama (100 $\mathrm{kg} \mathrm{K}_{2} \mathrm{O} / \mathrm{ha}$ ). Peningkatan dosis Trichokompos TKKS terformulasi hingga 30 ton/ha tidak begitu besar pengaruhnya terhadap parameter tersebut pada setiap dosis pupuk kalium. Hal ini disebabkan interaksi antara Tricho-kompos TKKS terformulasi 25 ton/ha dan pupuk kalium $100 \mathrm{~kg} \mathrm{~K} \mathrm{~K}_{2} \mathrm{O} / \mathrm{ha}$ memberikan nutrisi yang cukup dan seimbang terhadap pertumbuhan generatif tanaman bawang merah.

Tabel 5 juga menunjukkan bahwa peningkatan dosis Trichokompos TKKS terformulasi hingga 25 ton/ha meningkatkan bobot segar umbi per sampel sebesar 1,49 kali dibandingkan dengan pemberian 15 ton/ha. Semakin tinggi dosis Trichokompos TKKS terformulasi yang diberikan tentu semakin tinggi pula ketersediaan unsur hara di dalam tanah yang akan memberikan kontribusi terhadap peningkatan bobot segar umbi. Penampilan bobot segar umbi bawang merah per rumpun sampel disajikan pada Gambar 1.

Hasil penelitian Hapsoh, et al. (2012) menunjukkan bahwa bobot umbi ubi jalar paling tinggi diperoleh dari pemberian kompos TKKS dan interaksi dengan $75 \mathrm{~kg} \mathrm{KCl} / \mathrm{ha}$ dibandingkan tanpa kompos membutuhkan $225 \mathrm{~kg} \mathrm{KCl} / \mathrm{ha}$. Hasil penelitian Anom (2008) menunjukkan bahwa peningkatan pemberian Tricho-kompos jerami padi 10 ton/ha sampai 25 ton/ha pada panen II dapat meningkatkan berat segar tanaman sawi. 

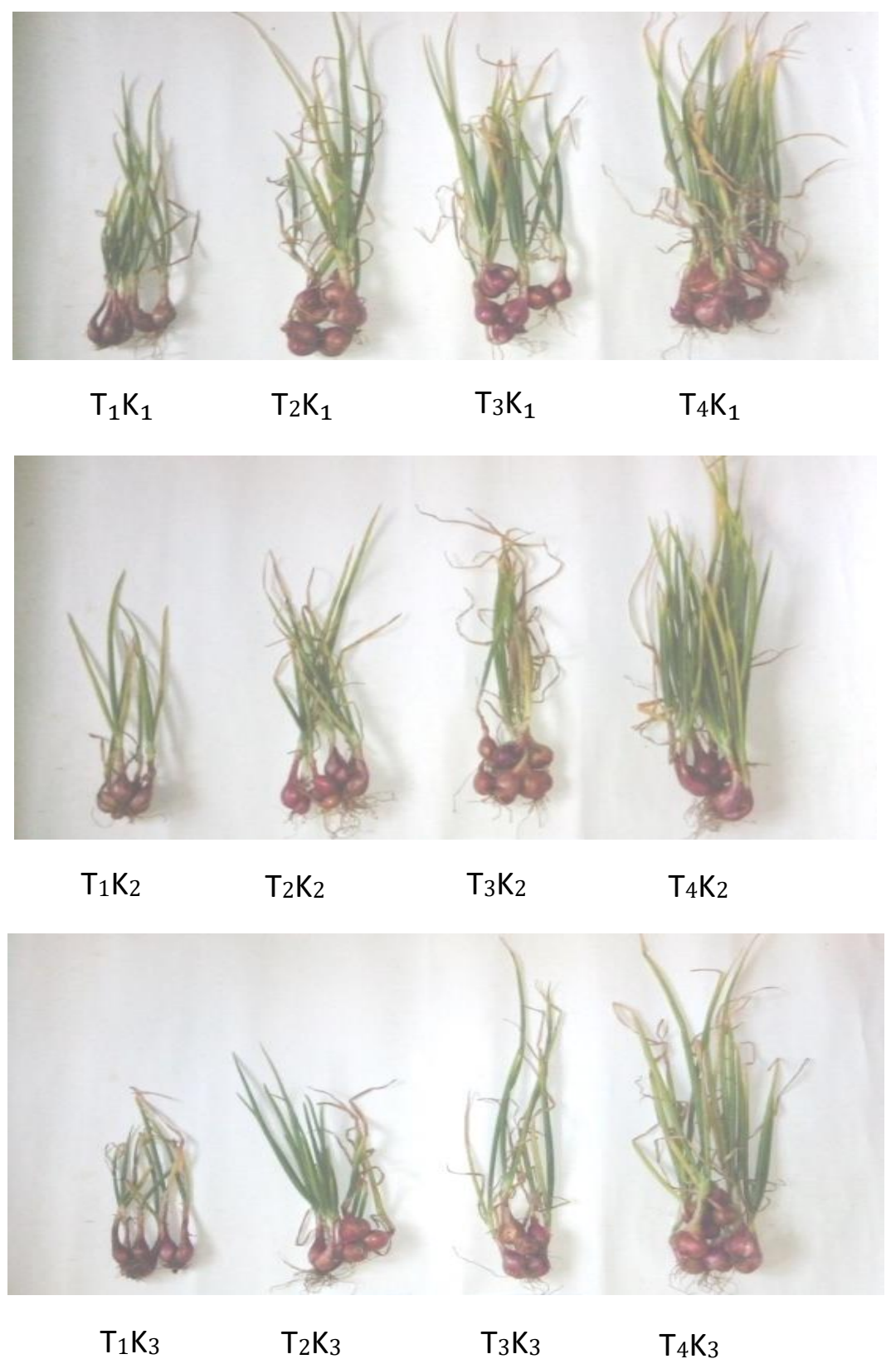

Gambar 1. Penampilan bawang merah dari kombinasi Trichokompos TKKS terformulasi (T) dosis 15, 20, 25 dan 30 ton/ha dan pupuk kalium (K) dosis 50, 100 dan $150 \mathrm{~kg} \mathrm{~K}_{2} \mathrm{O} / \mathrm{ha}$

Bahan organik yang berasal dari Trichokompos TKKS terformulasi dapat meningkatkan bobot segar umbi dengan cara memperbaiki sifat fisik tanah yaitu meningkatkan pori-pori tanah, memperbaiki tata udara dan air tanah, sehingga sistem perakaran menjadi lebih baik. Kondisi demikian akan meningkatkan serapan hara terutama $\mathrm{K}$ oleh akar tanaman yang akhirnya mempengaruhi bobot segar umbi bawang merah. Mengingat peranan $\mathrm{K}$ memacu translokasi hasil fotosintesis dari daun ke bagian tanaman yang lain terutama umbi.
Sulistyaningsih, et al. (2014) menyatakan bahwa dosis pupuk yang semakin tinggi dapat mempengaruhi kemampuan tanah dalam menyimpan air, dengan demikian memudahkan akar saat pengambilan unsur hara mineral dan air untuk metabolisme tanaman.

\section{KESIMPULAN}

\section{Kesimpulan}

Berdasarkan hasil penelitian, maka dapat disimpulkan beberapa hal sebagai berikut: 
1. Pemberian 25 ton/ha Trichokompos TKKS terformulasi dan $100 \mathrm{~kg} \mathrm{~K}_{2} \mathrm{O} / \mathrm{ha}$ mengurangi umbi diameter kecil sebesar 3 kali (228,6\%), meningkatkan umbi diameter besar sebesar 24 kali (2324,2\%), bobot segar umbi per rumpun sampel sebesar 1,7 kali (71,3\%) dibandingkan pemberian 15 ton/ha Trichokompos TKKS terformulasi pada dosis pupuk kalium yang sama (100 $\left.\mathrm{kg} \mathrm{K}_{2} \mathrm{O} / \mathrm{ha}\right)$.

2. Peningkatan dosis Trichokompos TKKS terformulasi dari 15 ke 25 ton/ha mengurangi umbi diameter kecil, sebaliknya meningkatkan umbi diameter besar dan bobot segar umbi per rumpun sampel. Peningkatan dosis ke 30 ton/ha masih berpengaruh terhadap peningkatan parameter tersebut kecuali jumlah umbi diameter kecil dan jumlah umbi diameter besar.

3. Peningkatan dosis pupuk kalium dari 50 ke 100 hingga $150 \mathrm{~kg} \mathrm{~K}_{2} \mathrm{O} / \mathrm{ha}$ tidak mempengaruhi seluruh parameter yang diamati.

\section{Saran}

Untuk mendukung pertumbuhan dan produksi tanaman bawang merah yang optimal di lahan gambut disarankan untuk menggunakan Trichokompos TKKS terformulasi dosis 25 ton/ha dan pupuk kalium $100 \mathrm{~kg} \mathrm{~K}_{2} \mathrm{O} / \mathrm{ha}$.

\section{DAFTAR PUSTAKA}

Anom E. 2008. Efek Residu Pemberian Trichokompos Jerami Padi Terhadap Pertumbuhan dan Produksi Sawi Hijau (Brassica juncea L.). Sagu. Vol. 7 No. 2: 7-12.

Badan Penelitian dan Pengembangan Pertanian. 2011. Peta Lahan Gambut Indonesia. http://bbsdlp.litbang.deptan.go.id. Akses tgl 09 September 2014.

Balai Penelitian Tanaman Sayuran. 2013. Budidaya Bawang Merah. Balitsa.litbang.deptan.go.id. Tanggal akses: 11 Agustus 2014.
Badan Pusat Statistik. 2013. Luas Panen, Produksi dan Produktivitas Bawang Merah 2009-2013. www.bps.go.id. Akses tgl 01 September 2014.

Hapsoh, Siregar LAM, Astuti LTW. 2012. Peningkatan Kualitas Ubi Jalar (Ipomoea batatas L.) Varietas Sari dan Beta 2 Akibat Aplikasi Kompos dan Pupuk KCl. Prosiding Seminar Nasional dan Rapat Tahunan BKSPTN Wilayah Barat.

Herviyanti, Achmad F, Sofyani R, Darmawan, Gusnidar, Saidi A. 2012. Pengaruh Pemberian Bahan Humat dari Ekstrak Batu Bara Muda (Subbituminus) dan Pupuk P Terhadap Sifat Kimia Ultisol serta Produksi Tanaman Jagung (Zea mays L.). Jurnal Solum. Vol.9 No.1: 1524.

Hidayat I M, Putrasameja S dan Azmi C. 2011. Persiapan Pelepasan Varietas Bawang Merah Umbi dan TSS. Laporan Kegiatan: 1804.17.a3.

Ichwan B. 2007. Pengaruh Dosis Trichokompos Terhadap Pertumbuhan dan Hasil Tanaman Cabe Merah. Jurnal Agronomi, Vol.11 No. 1 Hal.47-50.

Koheri A, Mariati, Simanungkalit T. 2015. Tanggap Pertumbuhan dan Produksi Bawang Merah (Allium ascalonicum L.) Terhadap Waktu Aplikasi dan Konsentrasi Pupuk KNO3. Jurnal Online Agroteknologi. Vol.3, No.1: 206-213.

Murniati, Silvina F, Hamzah A. 2010. Pemanfaatan Residu Abu Serbuk Gergaji dan Kascing pada Medium Gambut Setelah Penanaman Tomat Untuk Penanaman Bawang Merah. Jurnal Sagu. Vol.9 No.2: 4752.

Mustoyo, Simanjuntak B, Suprihati. 2013. Pengaruh Dosis Pupuk Kandang Terhadap Stabilitas Agregat Tanah Pada Sistem pertanian Organik. Jurnal Agric. Vol.5 No.1: 51-57.

Nadeak R, Yetti H, Khoiri A. 2014. Pengaruh Pemberian Trichokompos terhadap Pertumbuhan dan Produksi Tanaman Sawi (Brassica juncea 1.). Jom Faperta vol.1 No. 2.

Purbiati T, Umar A dan Supriyanto A. 2010. Pengkajian Adaptasi Varietas-Varietas 
Bawang Merah pada Lahan Gambut di Kalimantan Barat. BPTP- Kalimantan Barat

Refliaty, Endriani, Zurhalena. 2013. Efek Aplikasi Berbagai Formula Pupuk Bioorganik Trichokompos Terhadap Hasil dan Serapan Hara Oleh Kedelai pada Tanah Masam. Jurnal Penelitian Universitas Jambi Seri Sains. Vol. 15, No 2: 25-32.

Setiyowati, Haryanti S dan Hastuti RB. 2010. Pengaruh Perbedaan Konsentrasi Pupuk Organik Cair tehadap Produksi Bawang Merah (Allium ascalonicum L). BIOMA. Vol. 12, No. 2, Hal. 44-48.

Sulistyaningsih LN, Susilawati, dan Sitanggang E. 2014. Respon Pertumbuhan Tanaman Ganyong Merah (Canna edulis Ker) terhadap
Pemberian Pupuk Nitrogen dan Kalium. Prosiding Seminar Nasional Lahan Suboptimal. ISBN: 979-587-529-9.

Sumarni N, Hidayat A. 2005. Budidaya Bawang Merah, Panduan Teknis PTT Bawang Merah No. 3. Balai Penelitian Tanaman Sayuran.

Sumarni N, Rosliani R, Basuki RS, Hilman Y. 2012. Pengaruh Varietas, Status K-Tanah, Dosis Pupuk Kalium Terhadap Pertumbuhan, Hasil Umbi dan Serapan Hara K Tanaman Bawang Merah. Jurnal Hort. 22(3):233-241.

Yasin S, Oktalinda Y, Gusnidar. 2010. Perbaikan Kesuburan Tanah Regosol dengan Bahan Organik Untuk Tanaman Melon (Curcumis melo L.). Jurnal Jerami. Vol.3 No. 3. 